\title{
Exposure of Xenopus laevis tadpoles to finasteride, an inhibitor of 5- $\alpha$ reductase activity, impairs spermatogenesis and alters hypophyseal feedback mechanisms
}

\author{
R Urbatzka ${ }^{1}$, B Watermann ${ }^{2}$, I Lutz ${ }^{1}$ and W Kloas ${ }^{1,3}$ \\ ${ }^{1}$ Department of Inland Fisheries, IGB, Leibniz-Institute of Freshwater Ecology and Inland Fisheries, Mueggelseedamm 301,12587 Berlin, Germany \\ ${ }^{2}$ Limnomar, Bei der Neuen Muenze 11, 22145 Hamburg, Germany \\ ${ }^{3}$ Department of Endocrinology, Institute of Biology, Humboldt-University, Invalidenstrasse 43, 10115 Berlin, Germany \\ (Correspondence should be addressed to R Urbatzka who is now at Centre of Marine and Environmental Research, Rua dos Bragas 289, 4050-123 Porto, Portugal; \\ Email: rurbatzka@ ciimar.up.pt)
}

\begin{abstract}
Sexual steroids have major regulatory functions in gonadal development, maturation of gametes and sexual differentiation in vertebrates. Previous studies in amphibians provided evidence that dihydrotestosterone and activity of 5- $\alpha$ reductases might play a significant role in androgen-mediated reproductive biology. To test the involvement of $5-\alpha$ reductases in maturation of gametes in amphibians, Xenopus laevis was exposed to finasteride (FIN), a known inhibitor of 5- $\alpha$ reductase enzyme activity. In a long-term exposure from stage 46 to 66 , severe disruption of spermatogenesis was observed in histological analysis of testes as detected by occurrence of empty spermatocysts, while ovaries remained unaffected. Real-time PCR analyses of male and female brain revealed an increase of LH $\beta$ mRNA and a decrease of FSH $\beta$ mRNA in males, suggesting a signalling on testes that could result in increased steroidogenesis and reduced Sertoli cell proliferation. Accordingly, the mRNA expression of P450 side chain cleavage enzyme and 5- $\alpha$ reductase type 2 was increased in testes, while no effects could be observed on steroidogenic genes in ovaries. A short-term exposure to testosterone, FIN and testosterone +FIN showed that transient effects of FIN targeted males selectively and, in particular, interfered with the hypothalamus-pituitary-gonad axis. Furthermore, a negative feedback of testosterone on LH $\beta$ was observed on males and females. This study provides evidence that exposure of $X$. laevis to FIN, an inhibitor of 5- $\alpha$ reductases, impaired spermatogenesis and involved sex-specific hypophyseal feedback mechanisms.
\end{abstract}

Journal of Molecular Endocrinology (2009) 43, 209-219

\section{Introduction}

Synthesis of sexual steroids is a conserved process in vertebrates starting with cholesterol that is converted by the actions of multiple enzymes into testosterone. Testosterone can either exert androgen action by itself or can be further converted into dihydrotestosterone (DHT) or into 17ß-oestradiol (Payne \& Hales 2004). Leydig cells in testis and theca/granulosa cells in ovaries are the main producing cells of sexual steroids that are subsequently released into the bloodstream. Biological action in peripheral tissues often needs the conversion of testosterone into DHT that is accomplished by the enzyme $5-\alpha$ reductase. Two isozymes exist for 5 - $\alpha$ reductase, named type 1 (Srd5a1) and type 2 (Srd5a2), which are differentially distributed in many tissues. In rats, Srd5a2 is confined to androgendependent tissues, while Srd5al is present in various tissues (Torres et al. 2003). Especially, Srd5a2 activity is believed to play a key role in androgen-regulated reproductive biology.
In mammals, as in amphibians, the more potent androgen is DHT unlike in fish, where 11-ketotestosterone is the most potent androgen (Norris 1997). DHT promotes in humans and mammals the development of external genitalia or androgenic tissues like prostate, while testosterone is responsible for the development of male internal genitalia. Finasteride (FIN), a well-known inhibitor of $5-\alpha$ reductase activity with higher potency to Srd5a2 than to Srd5a1 (George et al. 1989, Prahalada et al. 1997, Ellsworth et al. 1998), was frequently used to experimentally unravel functions of 5 - $\alpha$ reductases being involved in male pattern hair loss (Kawashima et al. 2004) or benign prostate hyperplasia or prostate cancer (Luo et al. 2003). If administered in utero, external genitalia were feminized in rats (ImperatoMcGinley et al. 1992) or developed abnormalities in rhesus monkeys (Prahalada et al. 1997). Humans with deficiency of Srd5a2 developed feminized genitalia (Imperato-McGinley et al. 1981), and polymorphisms in $\mathrm{Srd5a2}$ gene were associated with differences in sperm concentration and motility (Elzanaty et al. 2006).

DOI: 10.1677/JME-09-0058 Online version via http://www.endocrinology-journals.org 
In the Srd5a2 gene promoter region, a progesterone and an androgen response element was identified in mouse, suggesting that different androgens might be able to regulate gene expression of Srd5a2 (Matsui et al. 2002). Testosterone regulated enzyme activity of 5- $\alpha$ reductase in an in vitro system (Andersson et al. 1989), mRNA expression of Srd5a2 in prostate of intact and castrated rats in vivo (Torres et al. 2003) and in rat brain in vivo and in vitro (Poletti et al. 1998). However, also DHT is described to induce 5- $\alpha$ reductase activity in rats (George et al. 1991). Effects of both testosterone and DHT are mediated via the androgen receptor, and it is known that some genes are differentially regulated by testosterone and DHT respectively (Avila et al. 1998). The mechanism for this is still unclear, but it is proposed that especially in peripheral tissues with low testosterone level, specific action of $5-\alpha$ reduced androgens is needed.

In amphibians, some studies provided evidence that DHT is a decisive androgen for sexual differentiation in Xenopus laevis: DHT but not testosterone at a concentration of $10^{-8} \mathrm{M}$ induced sex reversal in an exposure experiment (Bögi et al. 2002, Kloas 2002), and a sex-specific pattern of Srd5a2 mRNA expression during ontogeny suggested an important function in male gamete maturation (Urbatzka et al. 2007). The aim of the present study was to analyse the effect of FIN on the development of gonads in X. laevis and to gain insights into the physiological function of $5-\alpha$ reductases in regulating reproductive biology of amphibians. Therefore, tadpoles of $X$. laevis were exposed to FIN during their sensitive phase of gonadal development and sexual differentiation with the intention to decrease the activities of $5-\alpha$ reductase enzymes in $X$. laevis. The effects of FIN on gonad histology of $X$. laevis were monitored at stage 66 , just after the completion of metamorphosis. Additionally, the expression of LH $\beta$ and FSH $\beta$ mRNA was analysed in brain samples and the expression of selected steroidogenic genes ( $\mathrm{P} 450$ side chain cleavage enzyme (P450scc), steroidogenic acute regulatory protein (StAR), Srd5a1, Srd5a2 and aromatase (Aro)) in gonad samples. In complement to the analysis of long-term effects of FIN, a shortterm exposure was conducted to analyse the transient effects of FIN. The short-term exposure included three treatment groups, testosterone, FIN and testosterone + FIN, to address the question of a potential regulation of $5-\alpha$ reductase by testosterone in amphibians, a regulation that was frequently observed in mammalian model species. In this study, X. laevis was used for the first time as a comparative model to unravel the potential function of $5-\alpha$ reductases on spermatogenesis in lower vertebrates.

\section{Material and methods}

\section{Exposure}

$X$. laevis was taken from the breeding stock of the Institute of Freshwater Ecology and Inland Fisheries, Berlin, Germany. Adult X. laevis was injected with human chorionic gonadotrophin (Sigma) into the dorsal lymph sac to induce spawning as described previously (Kloas et al. 1999). Fertilized eggs and tadpoles were reared in 50-1 tanks containing reconstituted tap water using deionized water supplemented with $2.5 \mathrm{~g}$ marine salt (Tropic Marin Meersalz, Tagis, Dreieich, Germany) per 10 l. Tanks were aerated and temperature was adjusted to $22 \pm 1{ }^{\circ} \mathrm{C}$. Tadpoles were kept at a $12 \mathrm{~h}$ light:12 h darkness cycle and were fed daily with Sera Micron (Sera GmbH, Heinsberg, Germany). The developmental stages of the tadpoles were determined according to the Normal Table of $X$. laevis (Nieuwkoop \& Faber 1994).

For a long-term exposure, tadpoles at stage 46 were transferred to a 10-1 aerated glass aquaria at a density of 30 tadpoles per tank containing 71 of reconstituted tap water. Tadpoles were exposed to FIN (APIN Chemicals Ltd, a gift of Dr John Ashby, Central Toxicology Laboratory, Cheshire, Syngenta, UK), a known 5 - $\alpha$ reductase enzyme inhibitor. FIN was dissolved in dimethylsulphoxide (DMSO, Sigma) and the highest soluble concentration was chosen for exposure, which did not recrystallize if added to the water. The final concentration of FIN was $7 \times 10^{-6} \mathrm{M}$ $(2 \cdot 66 \mathrm{mg} / \mathrm{l})$ and DMSO concentration was $0.0286 \%$. Exposure was conducted in duplicate tanks (total $n=60$ ) and included a solvent control. Water and chemicals were renewed every Monday, Wednesday and Friday. Tadpoles were sampled after the completion of metamorphosis (stage 66). Sex of tadpoles was determined by gross morphology of the gonads using a stereo microscope before gonads were fixed in Bouin's solution for $24 \mathrm{~h}$. Fixed gonads were transferred to $80 \%$ ethanol (EtOH) for $24 \mathrm{~h}$ and then stored in fresh $80 \% \mathrm{EtOH}$ until further processing for histological analyses. Further gonad and brain samples of male and female tadpoles were dissected, immediately snap frozen in liquid nitrogen and stored at $-80{ }^{\circ} \mathrm{C}$ until further analyses.

In the short-term exposure, tadpoles were reared in aerated glass aquaria until they reached stage 58 . At this stage, tadpoles were transferred to the exposure tanks in a density of 18 tadpoles per tank containing 71 of reconstituted tap water. Tadpoles were exposed to testosterone at a supraphysiological concentration of $10^{-7} \mathrm{M}$, to FIN at a concentration of $7 \times 10^{-6} \mathrm{M}$ and to a combination of both. A solvent control (DMSO $0.0867 \%$ ) and a control without solvent were included in the experimental set-up. Exposure lasted 
4 days and water and chemicals were changed daily. Brain and gonads of six male and female tadpoles were dissected at day 5, directly snap frozen in liquid nitrogen and stored at $-80^{\circ} \mathrm{C}$ until further analyses.

\section{Histology}

From the long-term exposure, six males and six females of the control and the FIN treatment were analysed for histological alterations of the gonads. From paraffin blocks, 3-4 $\mu \mathrm{m}$ sections were cut using a microtome. Tissue sections were deparaffinized in xylene for 15 min, washed sequentially in $96,90,70,50$ and $30 \%$ $\mathrm{EtOH}$ (2 min each) and in aqua dest. for $5 \mathrm{~min}$. Subsequently, one set of sections was stained with haematoxylin-eosin, while another set was stained by immunocytochemistry for the proliferating cell nuclear antigen (PCNA) as indication for cell proliferation. Heat-induced epitope retrieval was performed by transfer of the slides into a jar containing Sorensen's citrate buffer ( $\mathrm{pH} 6)$ on a hot water bath $\left(96-99^{\circ} \mathrm{C}\right.$ ) for $30 \mathrm{~min}$. After cooling down the slides for $20 \mathrm{~min}$ at room temperature, the slides were washed with PBS and aqua dest. Endogenous peroxidase was quenched in $3 \%$ hydrogen peroxide for 5 min with subsequent rinsing in PBS. We applied $100 \mu \mathrm{l}$ of anti-PCNA to the slide, which was incubated at room temperature in a humidity chamber for $30 \mathrm{~min}$ and rinsed in PBS. The working concentration of anti-PCNA was 1:200, diluted in PBS. Next, $100 \mu \mathrm{l}$ of peroxidase were added to the slide, followed by incubation of the slide for $30 \mathrm{~min}$ in a humidity chamber and rinsing with PBS. The final step comprised the application of the chromagen solution NovaRED, incubation in a humidity chamber for $15 \mathrm{~min}$, washing in aqua dest. for $5 \mathrm{~min}$ and counterstaining of the slides with haematoxylin.

\section{RNA isolation and reverse transcription}

Extraction of total RNA of brain samples of tadpoles from the long-term exposure and brain and gonad samples of tadpoles from the short-term exposure was performed by using RNA extraction kits of Qiagen (RNeasy Micro Kit, RNeasy Mini Kit), according to the instructions of the manufacturer and included on-column DNAse ingestion (Qiagen). Transcription of RNA into cDNA was accomplished by reverse transcriptase reaction (RT) and was performed with $1 \mu \mathrm{g}$ total RNA for the brain samples and with $200 \mathrm{ng}$ total RNA for the gonad samples. For RT of brain samples, $7.5 \mathrm{pM}$ poly (dT) primer (Biometra, Göttingen, Germany), $10 \mathrm{mM}$ dNTP (Qbiogene, Heidelberg, Germany) and $10 \mathrm{U}$ AMV reverse transcriptase (Finnzymes, Espoo, Finland) were applied in a $30 \mu \mathrm{l}$ reaction, while for RT of gonad samples, $10 \mathrm{U}$ AffinityScript reverse transcriptase (Stratagene, Amsterdam, The Netherlands) were used in a $20 \mu$ reaction.

\section{Real-time RT-PCR}

Amplifications of cDNA specific for LH $\beta$, FSH $\beta$, P450scc, StAR, Srd5a1, Srd5a2, Aro and elongation factor $1-\alpha$ as housekeeping gene of $X$. laevis were carried out by using real-time RT-PCR. Amplification was carried out in a thermal cycler (Stratagene, Mx3000P) using SYBR Green. The following thermal cycling conditions were applied: $7 \mathrm{~min} 40 \mathrm{~s}$ at $95^{\circ} \mathrm{C}$ followed by 40 cycles of $17 \mathrm{~s}$ at $95^{\circ} \mathrm{C}, 25 \mathrm{~s}$ at $62^{\circ} \mathrm{C}$ and $25 \mathrm{~s}$ at $72^{\circ} \mathrm{C}$. Melting curve analyses were performed with the following setting: $40 \mathrm{~s}$ at $95^{\circ} \mathrm{C}, 30 \mathrm{~s}$ at $55^{\circ} \mathrm{C}$ and $30 \mathrm{~s}$ at $95^{\circ} \mathrm{C}$. For all PCRs, cDNA was diluted 1:5 (brain samples) or 1:10 (gonad samples), and $3 \mu \mathrm{l}$ of diluted cDNA were mixed in a $25 \mu \mathrm{l}$ reaction with $10 \mathrm{mM}$ dNTP (Qbiogene), 1:40•000 SYBR (Invitrogen), 1:200 ROX (Invitrogen), $2 \mathrm{mM} \mathrm{MgCl}_{2}, 100-400 \mathrm{pM}$ forward and reverse primer and $1 \mathrm{U}$ Platinum Taq-Polymerase (Invitrogen).

Primers were designed according to sequences published in the National Centre for Biotechnology Information. All sequences were derived from $X$. laevis with the exception of Srd5al and Srd5a2, which were deduced from Xenopus tropicalis. Table 1 lists the sequences of the designed primers. To test specificity of the PCR products, the bands were run on an agarose

Table 1 Overview about primer sequences used for real-time RT-PCR of various cDNAs related to the hypothalamus-pituitary-gonad axis of Xenopus laevis

Primer sequence, forward $\left(5^{\prime}-3^{\prime}\right)$

CACTGACGCTTCTGGGGTTCTAC

LH $\beta$, luteinizing hormone $\beta$-subunit $\mathrm{FSH} \beta$, follicle stimulating hormone, $\beta$-subunit Srd5a1, steroid $5-\alpha$ reductase, polypeptide 1 Srd5a2, steroid $5-\alpha$ reductase, polypeptide 2 Aro, aromatase

$\mathrm{P} 450$ scc, $\mathrm{P} 450$ side chain cleavage enzyme StAR, steroidogenic acute regulatory protein $E F 1-\alpha$, elongation factor $1-\alpha$ chain
TGCTCGTTCTGTGTTGGAAGATG

CTGAACCTCTTGGCTATG

CTTATCCTGCTGCTTATG

CGGTTCCATATCGTTACTTCC

CAGTGTTGGCCAGGATTTTGT

AACCCAAATGTCAAGGAAGTCAAG

ACCGCACAGGTTATCATC
Primer sequence, reverse $\left(5^{\prime}-3^{\prime}\right)$

GATTGGGCAGTCGTCTTTCTCT

CCTGTTTGATGAGTGGATGCTTTG

GATGCCTAACTCGGATTG

AGTCCTGTGGAAATAGTG

GCATCTTCCTCTCAATGTCTG

GCGGAAGAGCTCATTGGTCAG

ACAAAATCCCGGGCCCCTACAATA

CAACAATGGCAGCATCTC 
gel, extracted (QIAquick, Gel extraction kit, Qiagen) and forwarded to automated sequencing (SeqLab, Sequence Laboratories, Göttingen, Germany). Sequence comparisons by BLAST and sequence alignments (BioEdit Software, Version 7.0.9.0, Carlsbad, CA, USA) confirmed the specificity of amplified PCR products.

\section{Data analysis and statistics}

MxPro software (Stratagene) was used to analyse realtime PCR data using the $\Delta \Delta C_{\mathrm{t}}$ method, including the PCR efficiencies of the genes (ranging from 91.6 to $104.5 \%$ ). Values of the mRNA expressions of the target genes were normalized by the values of the housekeeping gene. After testing normal distribution, data of long-term exposure were analysed with unpaired $t$-tests. For data of short-term exposure, one-way ANOVA was used to examine significant differences between the mRNA expressions of the treatments. Either Tukey's test or Dunnett's T3-test was applied depending on the outcome of testing equality of variance by the Levene's test. Histological data were analysed by using Mann-Whitney $U$ test. For all statistical analyses, differences were regarded to be significant if $P$ was $<0 \cdot 05$.

\section{Results}

\section{Long-term exposure}

Mortality of tadpoles during exposure was very low and was $2 \%$ in control tanks (one individual) and $0 \%$ in FIN treatment tanks. No differences between control and FIN treatment groups were observed regarding the time needed to complete metamorphosis and their total length at stage 66 . Tadpoles developed from stage 46 to stage 66 in about 6 weeks and the mean length was $1 \cdot 8 \pm 0.2 \mathrm{~cm}$. Exposure of $X$. laevis tadpoles during ontogeny to FIN did not affect the sex ratio of tadpoles. Sex ratio in the FIN treatment group was not significantly different from the solvent control group with $60 \%$ males and $40 \%$ females.

Histological analyses of gonads revealed that male $X$. laevis from the solvent control group had relatively immature testes containing mainly spermatogonia and spermatocytes in numerous spermatocysts (Fig. 1, panel A). A further maturation to spermatids or spermatozoa was not observed in these animals. Proliferation activity of spermatogonia and spermatocytes was high as indicated by PCNA staining (Fig. 1, panel B). FIN-exposed male $X$. laevis possessed comparable maturation stages as in the solvent control group, namely spermatogonia and spermatocytes but not spermatids or spermatozoa. In five out of six analysed FIN-treated males, empty cavities were observed in the tubules and this likely corresponded to former spermatocysts with secondary spermatogonia (Fig. 1, panel C). Quantitative analyses of male gonadal sections revealed a statistically significant occurrence of empty spermatocysts $(P<0 \cdot 01)$. While there was no significant difference, FIN-treated male animals seemed to have a lower number of tubuli, spermatogonia and spermatocytes (Table 2). Intensity of proliferation was dramatically reduced in all FIN-treated males compared with the solvent control group, indicated by the lower number of visible mitoses and reduced PCNA staining (Fig. 1, panel D).

In female $X$. laevis from the solvent control group, ovaries were in the maturation stage in that ovarian cavities were formed or expanded. In the cortical region, numerous germ cells and primary oocytes arranged in nests were observed (Fig. 1, panel E). Proliferation activity indicated by PCNA staining was moderate in germ cells and high in primary oocytes (Fig. 1, panel F). Stages of maturation and the structure of gonads of FIN-treated female X. laevis were similar compared with females from the solvent control (Fig. 1, panel G), and also proliferation activity was about the same (Fig. 1, panel $\mathrm{H}$ ). The development of an ovarian cavity was not observed in one ovary.

In brain samples of male $X$. laevis, LH $\beta$ mRNA expression was about ninefold increased in the FIN treatment group $(P<0 \cdot 001)$, while FSH $\beta$ mRNA expression was decreased in FIN-treated males $(P<0 \cdot 05$; Fig. 2$)$. In testes, P450scc and Srd5a2 mRNA were significantly increased $(P<0 \cdot 01)$, while no effects were observed for StAR, Srd5al and Aro mRNA expression (Fig. 2).

In brain of female $X$. laevis, the expression of both gonadotrophins was not altered by water-borne exposure to FIN (Fig. 3). In ovaries, no different expression was observed in the FIN treatment group relative to the solvent control for all analysed steroidogenic genes.

\section{Short-term exposure}

In male tadpoles from the 4 day exposure, LH $\beta$ mRNA in the brain was significant decreased by testosterone as well as by the combined exposure to testosterone and FIN. By contrast, exposure to FIN alone led to a significant increase in LH $\beta$ mRNA expression and was about eightfold higher than in the control and in the solvent control (Fig. 4). FSH $\beta$ mRNA expression was not changed by any treatment. In the gonads, P450scc mRNA expression was twofold elevated in response to FIN, while the other treatments had no effect. StAR, Srd5a1, Srd5a2 and Aro mRNA expression stayed at the same expression levels compared with both control groups.

In female tadpoles, LH $\beta$ mRNA in the brain was significantly decreased by testosterone and the combined exposure to testosterone and FIN compared with 

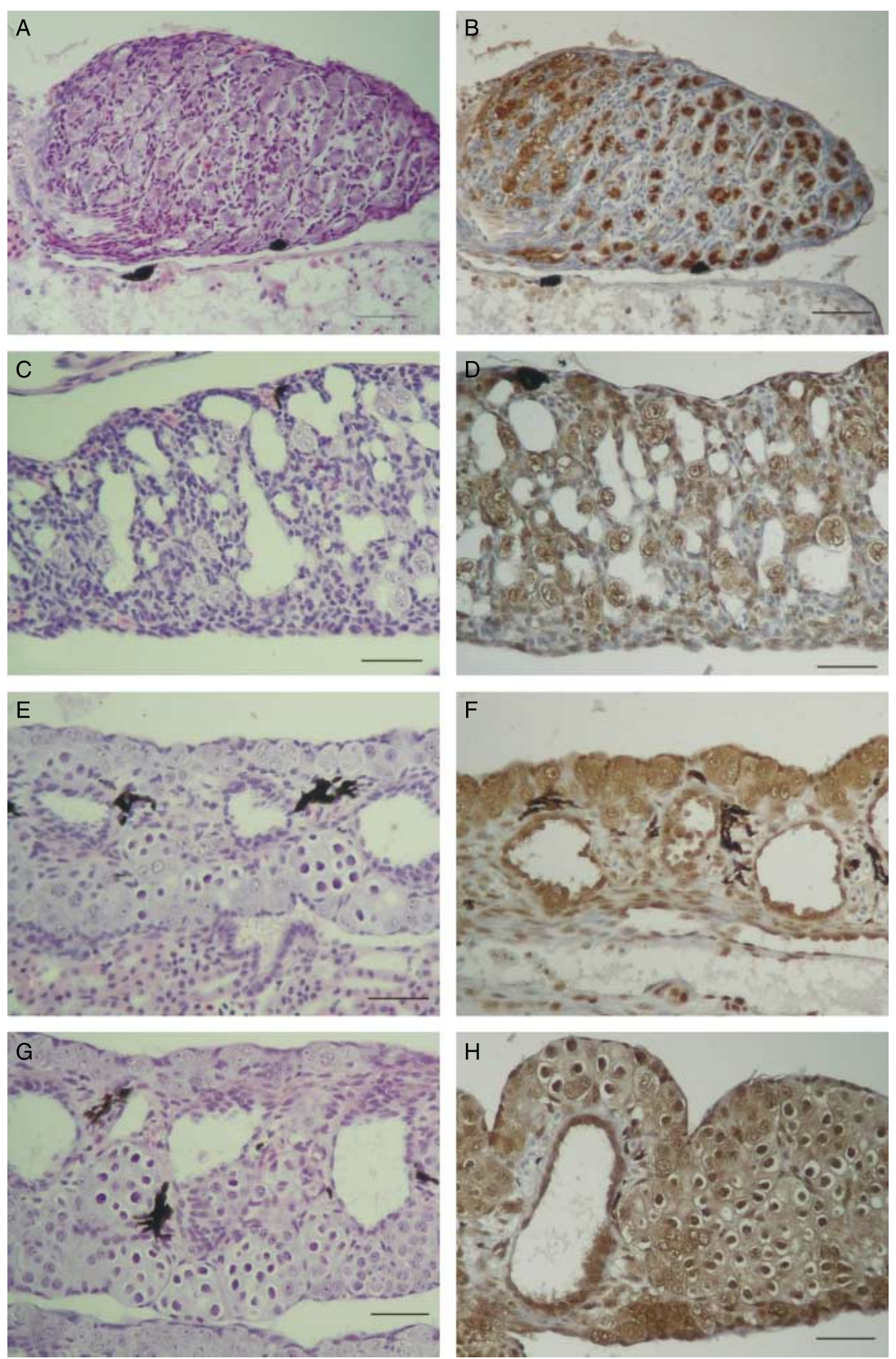

Figure 1 Selected pictures of histological sections of male and female gonads of $X$. laevis at stage 66 from the long-term exposure. On the left side of the figure (panels A, C, E and $G$ ), haematoxylin-eosin staining was applied; while on the right side (panels $B, D, F$ and $H$ ), proliferating cell nuclear antigen (PCNA) staining was used. Panels $A$ and $B$ refer to control males, panels $C$ and $D$ to FIN-treated males, panels $E$ and $F$ to control females and panels $\mathrm{G}$ and $\mathrm{H}$ to FIN-treated females. The bar indicates a distance of $50 \mu \mathrm{m}$. Full colour version of this figure available via http://dx.doi.org/10.1677/JME-09-0058.

the solvent control, corresponding to the results obtained in male tadpoles (Fig. 5). FIN alone did not change LH $\beta$ mRNA expression in females. No significant changes of mRNA expression were observed in the other analysed genes (FSH $\beta$, P450scc, StAR, Srd5a1, Srd5a2 and Aro) relative to control and solvent control.

\section{Discussion}

Tadpoles of $X$. laevis were exposed to FIN, a known inhibitor of 5 - $\alpha$ reductase enzyme activity (George et al. 1989, Ellsworth et al. 1998), during their sensitive phase of gonadal development and sexual 
Table 2 Results of quantification of histological analyses of testis of Xenopus laevis at stage 66 from the long-term exposure

\begin{tabular}{|c|c|c|c|c|c|c|c|c|c|}
\hline & tub $n$ & sptg $\%$ & sptg $n$ & sptc $\%$ & sptc $n$ & sptd & sptz & fsptcst & esptcst \\
\hline \multicolumn{10}{|l|}{ SoCo } \\
\hline Mean & $11 \cdot 0$ & 44.5 & $20 \cdot 7$ & 55.5 & $39 \cdot 0$ & 0.0 & 0.0 & $59 \cdot 8$ & 0.0 \\
\hline Min & 0 & & 2 & & 1 & 0 & 0 & 4 & 0 \\
\hline Max & 40 & & 40 & & 115 & 0 & 0 & 132 & 0 \\
\hline S.D. & 3.5 & $26 \cdot 5$ & $6 \cdot 8$ & $26 \cdot 5$ & $5 \cdot 8$ & 0.0 & 0.0 & $13 \cdot 1$ & $5 \cdot 8$ \\
\hline Min & 0 & & 0 & & 4 & 0 & 0 & 0 & 4 \\
\hline Max & 8 & & 18 & & 19 & 0 & 0 & 25 & 18 \\
\hline Sign. diff. & - & & - & & - & - & - & - & * \\
\hline
\end{tabular}

Significant differences were analysed by Mann-Whitney $U$ test $\left({ }^{\star} P<0 \cdot 01\right)$. tub, tubules; sptg, spermatogonia; sptc, spermatocytes; fsptcst, filled spermatocysts; esptcst, empty spermatocysts; SoCo, solvent control; FIN, finasteride.

differentiation. In a previous study, an important function of 5 - $\alpha$-reduced metabolites was suggested for spermatogenesis, observing sex-specific mRNA expression pattern of $\mathrm{Srd} 5 \mathrm{a} 2$ in $X$. laevis tadpoles during their ontogeny at the beginning of gamete maturation (Urbatzka et al. 2007). The present study demonstrated that FIN affected specifically males and not females leading to a disruption of spermatogenesis and to altered mRNA expression of gonadotrophins in the brain and of steroidogenic genes in the gonads.

Histological analyses of gonads of male $X$. laevis tadpoles exposed to FIN revealed a severe disruption of spermatogenesis. Emptied cavities were observed in the analysed gonads that corresponded to former spermatocysts with secondary spermatogonia (Fig. 1) and a reduced proliferation activity in FIN-treated males. According to these results, it was shown in male rats during puberty that a peak of $5-\alpha$ reductases and 5 - $\alpha$-reduced metabolites coincided with the first wave of spermatogenesis, suggesting a role for 5 - $\alpha$ reductases in the initiation of spermatogenesis (Killian et al. 2003). In studies during adulthood, no effects of FIN on testicular histomorphology were found in rats (George et al. 1989, Rhoden et al. 2002) and dogs (Juniewicz et al. 1993). By contrast, a study performed in adult rats showed that administration of FIN suppressed the testosterone-induced restoration of spermatogenesis and demonstrated clearly a role for 5 - $\alpha$-reduced androgens in adult spermatogenesis (O'Donnell et al. 1996). In contrast to the specific mode of action of FIN, the antiandrogen flutamide (FLU) inhibits the action of various androgens at the androgen receptor, and exposure experiments demonstrated the importance of androgens in spermatogenesis in different vertebrates. If rats were exposed in utero to FLU, the death of testicular germ cells was observed in a concentration-dependent way mediated by apoptotic gene expression (Bozec et al. 2004). Fish exposed to
FLU experienced spermatocyte degeneration in fathead minnow (Jensen et al. 2004) or reduced numbers of spermatogenic cysts in male guppies (Kinnberg \& Toft 2003).

In contrast to the results obtained in male tadpoles, histological analyses of ovaries demonstrated no alterations in the FIN treatment group compared with the control group. The single finding of one female gonad without the forming of an ovarian cavity may be an effect of FIN, but has to be verified in future experiments. In tadpoles of Bufo bufo and Rana dalmatina, the inhibition of $5-\alpha$ reductase activity accelerated the ovarian differentiation in females, suggesting an inhibiting role for 5 - $\alpha$-reduced metabolites regarding the timing of ovarian differentiation and maybe also for oocyte maturation in females (Zaccanti et al. 1994, Petrini \& Zaccanti 1998). However, this finding could not be confirmed in the present study.

The analysis of gonadotrophin mRNA expression in male and female $X$. laevis from the long-term exposure revealed a sex-specific hypophyseal feedback mechanism. Selectively in males, LH $\beta$ mRNA was strongly increased in the FIN treatment group, while FSH $\beta$ mRNA was decreased (Fig. 2). LH is known to act mainly on steroidogenesis in gonads, while $\mathrm{FSH}$ is essential for Sertoli cell proliferation (Weltzien et al. 2004). Therefore, this observed regulation pattern could signal an increased steroidogenesis in testes and a reduced Sertoli cell proliferation that could potentially have caused the observed impairment of spermatogonia maturation considering the central role of Sertoli cells in germ cell development. Mitotic activity of Sertoli cells in fish was highest during spermatogonial proliferation and considered as an important factor determining testis size and sperm production (Schulz et al. 2005). The modulatory effect of FIN on gonadotrophin mRNA expression in male $X$. laevis is shown for the first time and demonstrated an involvement of 


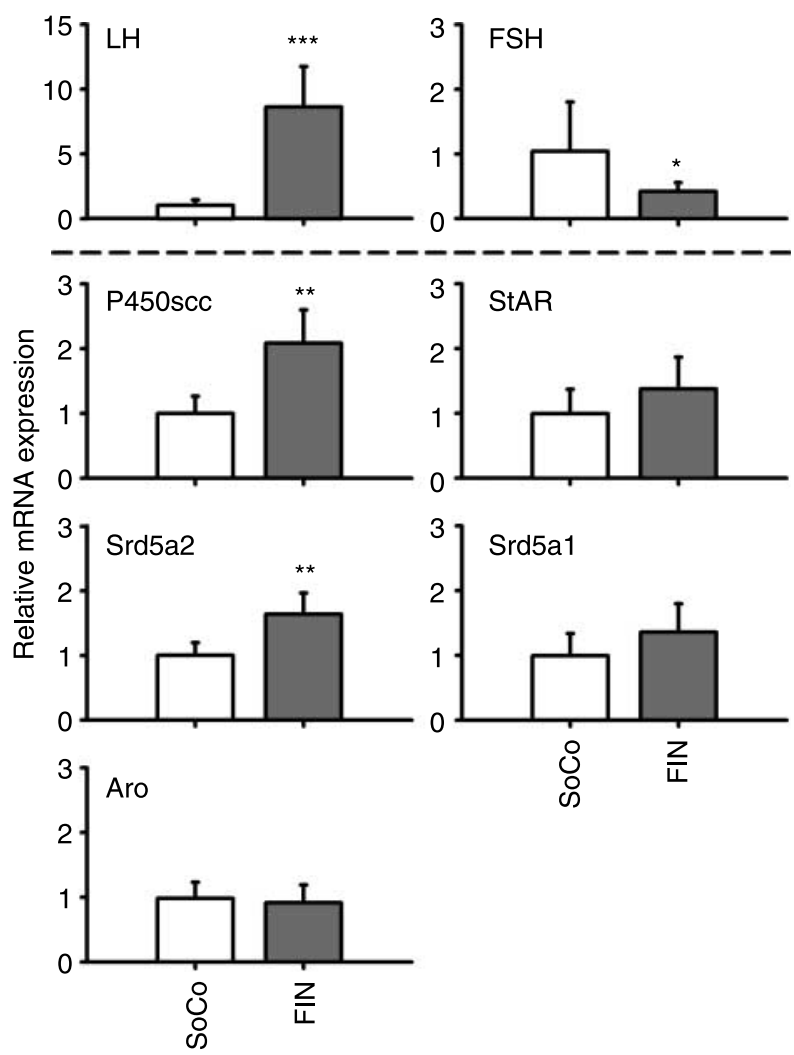

Figure 2 Real-time RT-PCR data of male $X$. laevis at stage 66 from long-term exposure. $\mathrm{LH} \beta$ and $\mathrm{FSH} \beta$ mRNA expression were analysed in brain, while P450 side chain cleavage enzyme (P450scc), steroidogenic acute regulatory protein (StAR), 5- $\alpha$ reductase type 2 (Srd5a2) and type 1 (Srd5a1) and aromatase (Aro) mRNA expressions were studied in gonads. Gene expression was normalized by the housekeeping gene elongation factor 1- $\alpha$. Data are represented as mean \pm s.D. derived from six individuals each. Significant differences between solvent control (SoCo) and finasteride treatment group (FIN) were analysed by $t$-test, $\left({ }^{\star \star \star} P<0.001 ;{ }^{* \star} P<0.01 ;{ }^{\star} P<0.05\right)$.

a physiological regulation of the $\mathrm{H}-\mathrm{P}-\mathrm{G}$ axis. This finding fits to a study in rats where a high dose of FIN ( $250 \mathrm{mg} / \mathrm{kg}$ per day) increased the plasma $\mathrm{LH}$ level that correlated with Leydig cell hyperplasia (Prahalada et al. 1994), while in another study, plasma LH level remained unchanged at a concentration of $20 \mathrm{mg} / \mathrm{kg}$ per day (Ribeiro \& Pereira 2005). The contrary regulation of $L H \beta$ and FSH $\beta$ mRNA expression in response to sexual steroids was confirmed in further experiments from our workgroup, even if the mechanism remains unclear (Urbatzka et al. 2008). From studies in fish, it is known that sexual steroids can regulate gonadotrophins differently, inhibiting one gene and stimulating the other (Sohn et al. 2001, Mateos et al. 2002).

In gonads of long-term-exposed animals, steroidogenic gene expression was changed in males, but not in females (Figs 2 and 3). FIN treatment increased
P450scc and Srd5a2 mRNA expression in testes, while StAR, Srd5al and Aro mRNA expression was not affected. It is well known that steroidogenesis is under the control of gonadotrophins (Weltzien et al. 2004), and therefore it is likely that increased LH $\beta$ mRNA in brain stimulated the transcription of P450scc. Interestingly, StAR mRNA expression was only slightly, but not significantly, increased. StAR is the enzyme responsible for cholesterol transport into the mitochondria where it is converted by $\mathrm{P} 450 \mathrm{scc}$ to pregnenolone (Arukwe 2008). Studies in fish showed that StAR and P450scc mRNA expression patterns were different under some experimental conditions regarding to exposure time, compounds and their concentration (Arukwe 2005, Kortner et al. 2009a,b). The increase of Srd5a2 mRNA in testis in FIN-treated animals is suggested to be a counter-regulation to the inhibition of $5-\alpha$ reductase enzyme activities and indicated the presence of a regulatory feedback loop. Thereby, the counterregulation could be driven directly by the assumed lower DHT level or by the observed feedback on LH $\beta$ mRNA expression. The Srd5al mRNA expression was only slightly increased, but not significant, and could be associated to the fact that FIN inhibits $5-\alpha$ reductase type 2 enzyme with higher potency than 5 - $\alpha$ reductase
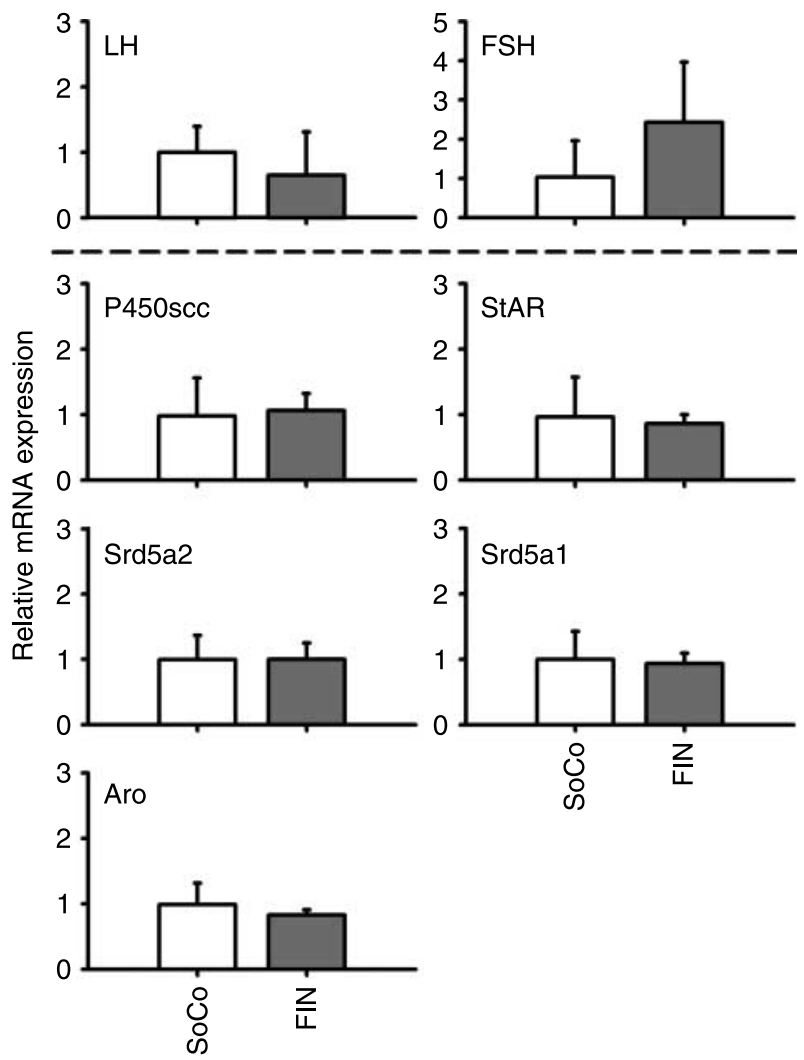

Figure 3 Real-time RT-PCR data of female $X$. laevis at stage 66 from the long-term exposure corresponding to Fig. 2. 


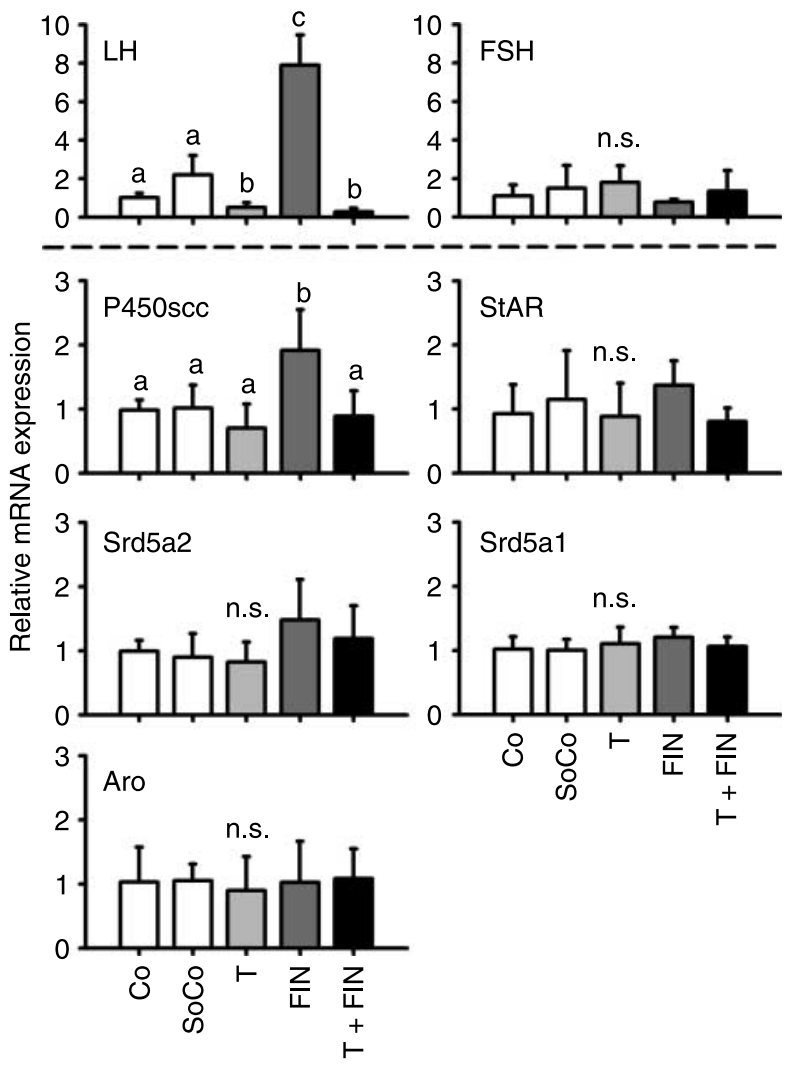

Figure 4 Real-time RT-PCR data of male $X$. laevis tadpoles at stage 58 exposed for 4 days to $10^{-7} \mathrm{M}$ testosterone $(\mathrm{T}), 7 \times$ $10^{-6} \mathrm{M}$ finasteride (FIN) or a combination of both (T+FIN). The short-term exposure included a solvent control group (SoCo) and a control group without solvent (Co). $\mathrm{LH} \beta$ and FSH $\beta$ mRNA expression were analysed in brain, while $\mathrm{P} 450$ side chain cleavage enzyme (P450scc), steroidogenic acute regulatory protein (StAR), 5- $\alpha$ reductase type 2 (Srd5a2) and type 1 (Srd5a1) and aromatase (Aro) mRNA expressions were studied in gonads. Gene expression was normalized by the housekeeping gene elongation factor $1-\alpha$. Data are represented as mean \pm s.D. derived from six individuals each. Different letters denote significant differences between treatment groups that were analysed by ANOVA (Tukey's or Dunnett's T3 test, $P<0.05$; n.s., not significant).

type 1 enzyme (Prahalada et al. 1997, Ellsworth et al. 1998). Aro mRNA expression stayed at the same expression level indicating no interference of FIN with oestrogen synthesis.

Male and female tadpoles at stage 58 were exposed to testosterone, FIN and a combination of both in a short-term exposure to analyse transient effects on gonadotrophin mRNA expression in the brain and steroidogenic gene expression in the gonads. Testosterone was chosen as an androgen since it has a stimulatory function on 5 - $\alpha$ reductase mRNA expression and enzyme activity in the peripheral tissues (Andersson et al. 1989, Poletti et al. 1998, Torres et al. 2003). LH $\beta$ mRNA expression was significantly reduced by testosterone and testosterone + FIN in males and females, but no effects were observed on FSH $\beta$ mRNA expression or steroidogenic gene expression in the gonads. The negative feedback of androgens on the $\mathrm{H}-\mathrm{P}-\mathrm{G}$ axis is known from previous studies in mature amphibians. DHT reduced the plasma LH level in male, adult Rana pipiens (Tsai et al. 2005) and methyldihydrotestosterone (MDHT) decreased the LH $\beta$ mRNA expression in male, adult $X$. laevis (Urbatzka et al. 2006). Thus, it is suggested that decreased LH $\beta$ mRNA levels in testosterone and testosterone + FIN treatment are due to negative feedback of testosterone. A regulation of Srd5a2 by testosterone like in mammals or in vitro (Andersson et al. 1989, George et al. 1991, Poletti et al. 1998, Torres et al. 2003) was not observed in this study for $X$. laevis. In accordance with the long-term exposure, the effect of FIN was restricted to males and included an increase in LH $\beta$ mRNA and P450scc mRNA indicating an increase in steroidogenesis mediated by feedback on LH. FIN treatment in rat resulted in an increase in testosterone and androstenedione, a decrease in DHT (George 1997) and additionally increased oestradiol in humans (Castro-Magana et al. 1996). If a similar effect of FIN on steroids is assumed in this study, the increased LH $\beta$ mRNA expression in the

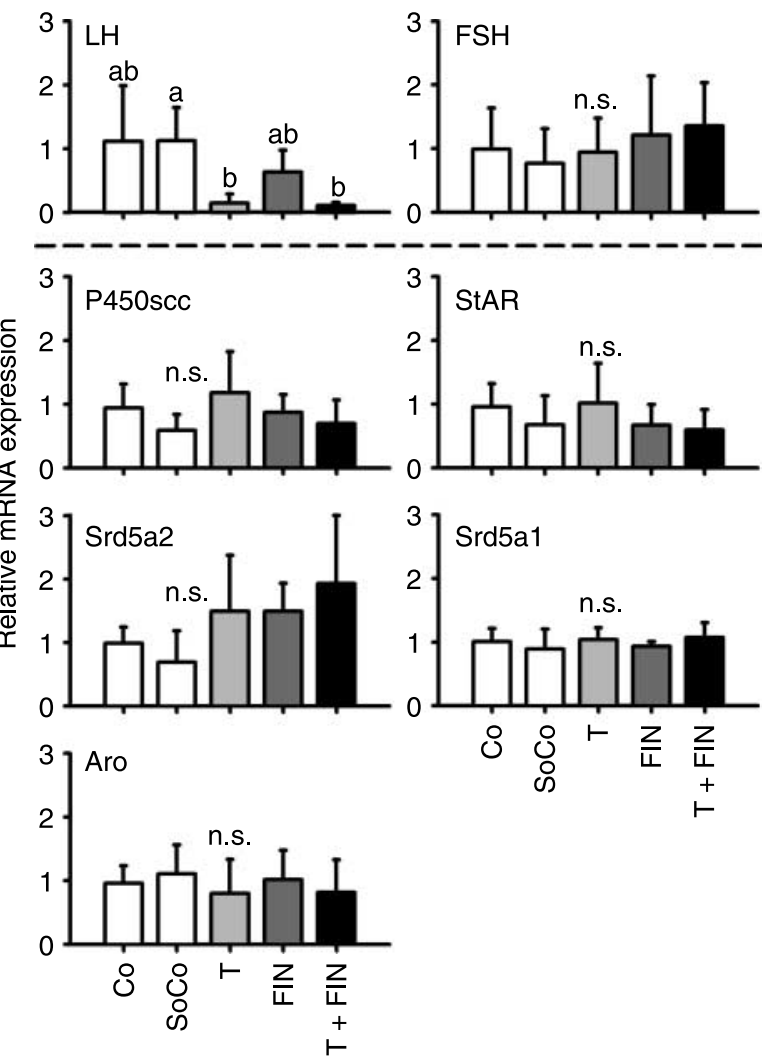

Figure 5 Real-time RT-PCR data of female $X$. laevis tadpoles at stage 58 corresponding to Fig. 4. 
FIN treatment group is unlikely to be induced by the increase in testosterone or oestrogens since exposure to testosterone was demonstrated in this study to inhibit LH $\beta$ mRNA expression, an effect also known for exposure of amphibians to oestrogens (Urbatzka et al. 2006). Furthermore, androstenedione is known to have only a low affinity to the androgen receptor and is therefore an improbable candidate for steroidal feedback. In contrary, we suggest that the increase of LH $\beta$ in the FIN treatment could be due to the assumed lower DHT levels, a regulation that would fit to another experiment where exposure to FLU, an androgen receptor antagonist, increased LH $\beta$ mRNA expression in males (Urbatzka et al. 2008). A decrease of FSH $\beta$ mRNA and an increase of Srd5a2 mRNA as detected in males from the long-term exposure could only slightly be observed in the short-term exposure and was not significant different from the control. Therefore, it may indicate that these effects are time dependent. Some effects may be unmasked only after a prolonged exposure time. Furthermore, transient effects could be mediated by altered enzyme levels, while long-term effects involve de novo synthesis of mRNA.

Interestingly, no effect of FIN was observed in females in the short- and long-term exposures either on gonadotrophin expression in the brain or on steroidogenic gene expression in ovaries. The reasons for these results remain speculative and may be owed to a differential regulation of feedback mechanisms in the brain.

The present study provided clear evidence that FIN affected the expression of gonadotrophin mRNA in long- and short-term exposures. However, the effect of FIN on gonadotrophins could be potentially mediated by the inhibition of $5-\alpha$ reductase activity or by a direct effect. The present data indicated an increased Srd5a2 mRNA expression in the long-term exposure as counter-regulation to the assumed inhibition of $5-\alpha$ reductase enzyme activity. This result is in line with the fact that FIN is a specific inhibitor of 5- $\alpha$ reductase type 2 enzyme activity in mammals (Prahalada et al. 1997, Ellsworth et al. 1998). Accordingly, specific inhibition of $5-\alpha$ reductase enzyme activity was reported in sea urchins (Wasson \& Watts 1998) suggesting that FIN is acting specifically in vertebrates and non-vertebrates. An assumed lower DHT level in the FIN treatment group could have affected the gonadotrophin mRNA expression in the pituitary, since it is well known that sexual steroids feedback on the hypothalamus and pituitary. In further experiments of our workgroup, it was demonstrated that LH $\beta$ mRNA expression in male $X$. laevis was increased in an exposure to the androgen receptor antagonist FLU (Urbatzka et al. 2008) providing further indications for this hypothesis. Nevertheless, both hypotheses are suggested to be possible until a proof of decreased enzymatic levels of $5-\alpha$ reductase or DHT levels is shown in response to FIN treatment in amphibians.

Summarizing, it was shown that exposure of $X$. laevis tadpoles to FIN, an inhibitor of 5 - $\alpha$ reductase activity, during the phase of gonadal development and sexual differentiation affected only the males and impaired spermatogenesis in testes of metamorphosed frogs. The long- and short-term exposures to FIN demonstrated a potential involvement of sex-specific hypophyseal feedback mechanisms, in particular an elevation of LH $\beta$ mRNA in brain and of P450scc mRNA in gonads. Only the long-term exposure revealed an additional decrease of FSH $\beta$ mRNA in brain and an increase of Srd5a2 mRNA in gonads. Decreased FSH $\beta$ mRNA expression may have caused a reduced Sertoli cell proliferation, important cells for germ cell development, while increased LH $\beta$ mRNA expression was suggested to stimulate steroidogenesis as counter-regulation to FIN.

\section{Declaration of interest}

The authors declare that there is no conflict of interest that could be perceived as prejudicing the impartiality of the research reported.

\section{Funding}

This research was funded in part by the European Union within the EU-project EASYRING, contract Nr. QLK4-CT-2002-02286.

\section{Acknowledgements}

We thank Dr John Ashby (Central Toxicology Laboratory, Cheshire, Syngenta, UK) for the gift of Finasteride.

\section{References}

Andersson S, Bishop RW \& Russell DW 1989 Expression cloning and regulation of steroid 5 alpha-reductase, an enzyme essential for male sexual differentiation. Journal of Biological Chemistry 264 $16249-16255$.

Arukwe A 2005 Modulation of brain steroidogenesis by affecting transcriptional changes of steroidogenic acute regulatory (StAR) protein and cholesterol side chain cleavage (P450scc) in juvenile Atlantic salmon (Salmo salar) is a novel aspect of nonylphenol toxicity. Environmental Science E Technology 39 9791-9798.

Arukwe A 2008 Steroidogenic acute regulatory (StAR) protein and cholesterol side-chain cleavage ( $\mathrm{P} 450 \mathrm{scc})$-regulated steroidogenesis as an organ-specific molecular and cellular target for endocrine disrupting chemicals in fish. Cell Biology and Toxicology 24 527-540.

Avila DM, Fuqua SA, George FW \& McPhaul MJ 1998 Identification of genes expressed in the rat prostate that are modulated differently by castration and finasteride treatment. Journal of Endocrinology $\mathbf{1 5 9}$ 403-411.

Bögi C, Levy G, Lutz I \& Kloas W 2002 Functional genomics and sexual differentiation in amphibians. Comparative Biochemistry and Physiology. Part B, Biochemistry E Eolecular Biology 133 559-570. 
Bozec A, Chuzel F, Chater S, Paulin C, Bars R, Benahmed M \& Mauduit C 2004 The mitochondrial-dependent pathway is chronically affected in testicular germ cell death in adult rats exposed in utero to anti-androgens. Journal of Endocrinology 183 79-90.

Castro-Magana M, Angulo M, Fuentes B, Canas A, Sarrantonio M, Arguello R \& Vitollo P 1996 Effect of finasteride on human testicular steroidogenesis. Journal of Andrology 17 516-521.

Ellsworth KP, Azzolina BA, Cimis G, Bull HG \& Harris GS 1998 Cloning, expression and characterization of rhesus macaque types 1 and 2 5alpha-reductase: evidence for mechanism-based inhibition by finasteride. Journal of Steroid Biochemistry and Molecular Biology 66 271-279.

Elzanaty S, Giwercman YL \& Giwercman A 2006 Significant impact of 5alpha-reductase type 2 polymorphisms on sperm concentration and motility. International Journal of Andrology 29 414-420.

George FW 1997 Androgen metabolism in the prostate of the finasteride-treated, adult rat: a possible explanation for the differential action of testosterone and 5 alpha-dihydrotestosterone during development of the male urogenital tract. Endocrinology 138 871-877.

George FW, Johnson L \& Wilson JD 1989 The effect of a 5 alphareductase inhibitor on androgen physiology in the immature male rat. Endocrinology 125 2434-2438.

George FW, Russell DW \& Wilson JD 1991 Feed-forward control of prostate growth: dihydrotestosterone induces expression of its own biosynthetic enzyme, steroid 5 alpha-reductase. PNAS $\mathbf{8 8}$ 8044-8047.

Imperato-McGinley J, Peterson RE \& Gautier T 1981 Male pseudohermaphroditism secondary to 5a-reductase deficiency: a review. In Fetal Endocrinology, pp 359-382. Eds MJ Novy \& JA Resko. New York: Academic Press.

Imperato-McGinley J, Sanchez RS, Spencer JR, Yee B \& Vaughan ED 1992 Comparison of the effects of the 5 alpha-reductase inhibitor finasteride and the antiandrogen flutamide on prostate and genital differentiation: dose-response studies. Endocrinology 131 $1149-1156$

Jensen KM, Kahl MD, Makynen EA, Korte JJ, Leino RL, Butterworth BC \& Ankley GT 2004 Characterization of responses to the antiandrogen flutamide in a short-term reproduction assay with the fathead minnow. Aquatic Toxicology 70 99-110.

Juniewicz PE, Hoekstra SJ, Lemp BM, Barbolt TA, Devin JA, Gauthier E, Frenette G, Dube JY \& Tremblay RR 1993 Effect of combination treatment with zanoterone (WIN 49596), a steroidal androgen receptor antagonist, and finasteride (MK-906), a steroidal 5 alpha-reductase inhibitor, on the prostate and testes of beagle dogs. Endocrinology 133 904-913.

Kawashima M, Hayashi N, Igarashi A, Kitahara H, Maeguchi M, Mizuno A, Murata Y, Nogita T, Toda K, Tsuboi R et al. 2004 Finasteride in the treatment of Japanese men with male pattern hair loss. European Journal of Dermatology 14 247-254.

Killian J, Pratis K, Clifton RJ, Stanton PG, Robertson DM \& O'Donnell L 2003 5alpha-reductase isoenzymes 1 and 2 in the rat testis during postnatal development. Biology of Reproduction 68 1711-1718.

Kinnberg K \& Toft G 2003 Effects of estrogenic and antiandrogenic compounds on the testis structure of the adult guppy (Poecilia reticulata). Ecotoxicology and Environmental Safety 54 16-24.

Kloas W 2002 Amphibians as a model for the study of endocrine disruptors. International Reviews of Cytology 216 1-57.

Kloas W, Lutz I \& Einspanier R 1999 Amphibians as a model to study endocrine disruptors: II. Estrogenic activity of environmental chemicals in vitro and in vivo. Science of the Total Environment $\mathbf{2 2 5}$ 59-68.

Kortner TM, Rocha E \& Arukwe A 2009a Androgenic modulation of early growth of Atlantic cod (Gadus morhua L.) previtellogenic oocytes and zona radiata-related genes. Journal of Toxicology and Environmental Health. Part A 72 184-195.

Kortner TM, Rocha E \& Arukwe A 2009b Previtellogenic oocyte growth and transcriptional changes of steroidogenic enzyme genes in immature female Atlantic cod (Gadus morhua L.) after exposure to the androgens 11-ketotestosterone and testosterone. Comparative Biochemistry and Physiology. Part A, Molecular $\mathcal{E}$ Integrative Physiology 152 304-313.

Luo J, Dunn TA, Ewing CM, Walsh PC \& Isaacs WB 2003 Decreased gene expression of steroid 5 alpha-reductase 2 in human prostate cancer: implications for finasteride therapy of prostate carcinoma. Prostate 57 134-139.

Mateos J, Mananos E, Carrillo M \& Zanuy S 2002 Regulation of follicle-stimulating hormone (FSH) and luteinizing hormone (LH) gene expression by gonadotropin-releasing hormone $(\mathrm{GnRH})$ and sexual steroids in the Mediterranean Sea bass. Comparative Biochemistry and Physiology. Part B, Biochemistry E Molecular Biology 132 75-86.

Matsui D, Sakari M, Sato T, Muravama A, Takada I, Kim M, Takevama K \& Kato S 2002 Transcriptional regulation of the mouse steroid 5 alpha-reductase type II gene by progesterone in brain. Nucleic Acids Research 30 1387-1393.

Nieuwkoop PD \& Faber J 1994. Normal Table of Xenopus laevis (Daudin), New York: Garland Publishing Inc.

Norris DO 1997 Vertebrate Endocrinology, edn 3. pp 634. San Diego: Academic Press.

O’Donnell L, Stanton PG, Wreford NG, Robertson DM \& McLachlan RI 1996 Inhibition of 5 alpha-reductase activity impairs the testosterone-dependent restoration of spermiogenesis in adult rats. Endocrinology 137 2703-2710.

Payne AH \& Hales DB 2004 Overview of steroidogenic enzymes in the pathway from cholesterol to active steroid hormones. Endocrine Reviews 25 947-970.

Petrini S \& Zaccanti F 1998 The effects of aromatase and 5 alphareductase inhibitors, antiandrogen, and sex steroids on Bidder's organs development and gonadal differentiation in Bufo bufo tadpoles. Journal of Experimental Zoology 280 245-259.

Poletti A, Negri-Cesi P, Rabuffetti M, Colciago A, Celotti F \& Martini L 1998 Transient expression of the 5alpha-reductase type 2 isozyme in the rat brain in late fetal and early postnatal life. Endocrinology 139 2171-2178.

Prahalada S, Majka JA, Soper KA, Nett TM, Bagdon WJ, Peter CP, Burek JD, MacDonald JS \& van Zwieten MJ 1994 Leydig cell hyperplasia and adenomas in mice treated with finasteride, a 5 alpha-reductase inhibitor: a possible mechanism. Fundamental and Applied Toxicology 22 211-219.

Prahalada S, Tarantal AF, Harris GS, Ellsworth KP, Clarke AP, Skiles GL, MacKenzie KI, Kruk LF, Ablin DS, Cukierski MA et al. 1997 Effects of finasteride, a type 25 -alpha reductase inhibitor, on fetal development in the rhesus monkey (Macaca mulatta). Teratology $\mathbf{5 5}$ 119-131.

Rhoden EL, Gobbi D, Menti E, Rhoden C \& Teloken C 2002 Effects of the chronic use of finasteride on testicular weight and spermatogenesis in Wistar rats. BJU International 89 961-963.

Ribeiro CM \& Pereira OC 2005 5alpha-reductase 2 inhibition impairs brain defeminization of male rats: reproductive aspects. Pharmacology, Biochemistry, and Behavior 82 228-235.

Schulz RW, Menting S, Bogerd J, Franca LR, Vilela DAR \& Gondinho HP 2005 Sertoli cell proliferation in the adult testis - evidence from two fish species belonging to different orders. Biology of Reproduction 73 891-898.

Sohn YC, Kobayashi M \& Aida K 2001 Regulation of gonadotropin beta subunit gene expression by testosterone and gonadotropinreleasing hormones in the goldfish, Carassius auratus. Comparative Biochemistry and Physiology. Part B, Biochemistry E Molecular Biology 129 419-426.

Torres JM, Gomez-Capilla JA, Ruiz E \& Ortega E 2003 Semiquantitative RT-PCR method coupled to capillary electrophoresis to study 5alpha-reductase mRNA isozymes in rat ventral prostate in different androgen status. Molecular and Cellular Biochemistry 250 $125-130$ 
Tsai PS, Kessler AE, Jones JT \& Wahr KB 2005 Alteration of the hypothalamic-pituitary-gonadal axis in estrogen- and androgentreated adult male leopard frog, Rana pipiens. Reproductive Biology and Endocrinology 32.

Urbatzka R, Lutz I, Opitz R \& Kloas W 2006 Luteinizing hormone, follicle stimulating hormone, and gonadotropin releasing hormone mRNA expression of Xenopus laevis in response to endocrine disrupting compounds affecting reproductive biology. General and Comparative Endocrinology 146 119-125.

Urbatzka R, Lutz I \& Kloas W 2007 Aromatase, steroid-5-alphareductase type 1 and type 2 mRNA expression in gonads and in brain of Xenopus laevis during ontogeny. General and Comparative Endocrinology 153 280-288.

Urbatzka R, Lorenz C, Wiedemann C, Lutz I \& Kloas W 2008 Ontogenetic mRNA expression of gonadotropins and their endocrine regulation by (anti)estrogens and (anti)androgens in Xenopus laevis. 24th Conference of European Comparative Endocrinologists (CECE 2008), Genoa, Italy, 66.
Wasson KM \& Watts SA 1998 Proscar (Finasteride) inhibits 5 alphareductase activity in the ovaries and testes of Lytechinus variegatus Lamarck (Echinodermata: Echinoidea). Comparative Biochemistry and Physiology. Part C, Pharmacology, Toxicology E Endocrinology 120 425-431.

Weltzien FA, Andersson E, Andersen O, Shalchian-Tabrizi K \& Norberg B 2004 The brain-pituitary-gonad axis in male teleosts, with special emphasis on flatfish (Pleuronectiformes). Comparative Biochemistry and Physiology. Part A, Molecular E Integrative Physiology 137 447-477.

Zaccanti F, Petrini S, Rubatta ML, Stagni AM \& Giorgi PP 1994 Accelerated female differentiation of the gonad by inhibition of steroidogenesis in amphibia. Comparative Biochemistry and Physiology. Part A, Physiology 107 171-179.

Received in final form 26 May 2009

Accepted 24 June 2009

Made available online as an Accepted Preprint 24 June 2009 